\title{
Peer mentoring - is a virtual form of support a viable alternative?
}

\author{
Joanne Smailes $^{\mathrm{a} *}$ and Pat Gannon-Leary ${ }^{\mathrm{b}}$ \\ ${ }^{a}$ Academic Services, Northumbria University, Newcastle upon Tyne, UK; ${ }^{b}$ Bede Research \& \\ Consultancy UK, Newcastle upon Tyne, UK
}

(Received 15 July 2009; final version received 3 March 2011)

\begin{abstract}
Support systems are vital for university entrants and one established means of support is peer mentoring, which has the potential to improve student engagement and retention. Peer mentoring models are generally based on face-to-face contact. However, given the increasing number of higher education institutions using social media, might online models be beneficial in a peer mentoring context? This article describes a literature review and case study that considers the advantages and disadvantages of three potential virtual models to facilitate a peer mentoring scheme. The case study, undertaken at Northumbria University, UK, involved an investigation of mentoring needs and current usage of electronic media where special attention is afforded to a diverse student body. The three models discussed are virtual learning environments (VLE), social networking sites and virtual worlds. We find that the VLE is established within institutions but lacks excitement; social networking is popular particularly with younger students but there may be resentment if this appears to be appropriated by the institution; whilst virtual worlds are unfamiliar to many students and require advanced skills to use successfully. Based on these findings the social networking model is now being run as a pilot study by business programmes at Northumbria University.
\end{abstract}

Keywords: diversity; peer mentoring; student support; virtual learning environments

\section{Introduction}

It is well recognised that students' sense of identification with their peers is both important to their success and complex (Haythornthwaite 2008). Eggens, van der Werf, and Bosker (2007) note that personal networks affect student attainment, and Clifton et al. (2004) observe how peers give an individual the sense of coping and hence perceived control over academic progress.

Harvey, Drew, and Smith (2006) noted how students from lower-income families have less peer support to draw on, and go on to suggest that there is some correlation between socio-economic groups, first-year grades and the possibility of withdrawing from study (especially where family problems intervene).

Peer mentoring is a well-established method employed by higher education institutions to assist in the integration of students into university. The topic attracts a plethora of literature that is reviewed on a regular basis (Jacobi 1991; Ehrich,

*Corresponding author. Email: joanne.smailes@northumbria.ac.uk 
Hansford, and Tennent 2004; Terrion and Leonard 2007; Crisp and Cruz 2009). Peer mentoring involves more experienced students supporting new students during their academic and personal development, and has been found to be effective in: improving the first-year experience of students (see, for example, Watson 2000; Hensen 2003; Mee-Lee and Bush 2003; Farrell et al. 2004; Tariq 2005); increasing student retention (see, for example, Packham and Miller 2000; Boud, Cohen, and Sampson 2003; Muldoon 2008); improving achievement, with some suggesting peer mentoring users gain higher mean grades than non-users (see, for example, Congos, Langsham, and Schoeps 1998; Ashwin 2002; 2003); and improving the interpersonal skills of the mentors, which leads to enhanced employability (see, for example, Congos and Stout 2003; McLean 2004; Muldoon 2008).

However, there are few studies that have specifically considered the role of peer mentoring in terms of student diversity. Best, Hajzler, and Henderson (2007) reported on how peer mentoring had been used as a technique for the improvement of the international student transition from one learning culture to another, and Devereux (2004) reports on the use of peer mentoring as a way to enhance intercultural relationships.

The key success factors consistently identified include appropriate mentor training and the inclusion of peer mentoring as part of the formal curriculum (Jacobi 1991; Ehrich Hansford, and Tennent. 2004; Terrion and Leonard 2007; Crisp and Cruz 2009).

In the 1990s, the concept of a 'community of practice' (CoP) was one of the most important developments in educational theory (Lave and Wenger 1998). Of particular note was the recognition that a $\mathrm{CoP}$ is not an exclusively academic notion (Wenger, McDermott, and Synder 2002). The concept of a CoP refers to the process of social learning that occurs - and shared socio-cultural practices that emerge and evolve - when people who have common goals interact as they strive towards those goals (Lave and Wenger 1998). In a community of learners the first purpose is not practice but rather the advancement of learning (Wubbels 2007). These two communities (of practice and of learning) converge when the learning experience combines with socio-cultural development of students, as in the case of support mechanisms such as peer mentoring that aid the enculturation process.

Smith and Bath (2006) suggest that as peer interactions, including the social, are essential determinants of graduate outcome, the notion of a learning community should be reinforced within any innovations for supporting student learning. Essentially, peer mentoring, which literature indicates is a sound principle, is designed to initiate CoPs amongst student cohorts.

However, attempts to introduce traditional models of peer mentoring at Northumbria University have had mixed fortunes. Recruitment and training of mentors, across a number of disciplines, has always been successful but, despite adhering to advice drawn from literature, first-year student attendance was often poor. To investigate this further, research via questionnaire and interview was conducted to identify whether there was actually a demand for peer mentoring from the students. Northumbria University has a diverse student group of over 26,500 students. Onequarter of students are over the age of 25, 23.0\% of are on part-time programmes and $13.1 \%$ are classed as international (the majority of whom originate from Asia). Questionnaire responses received from a representative sample of the diverse cohort $(n=309)$ showed there was a clear demand for peer mentoring as a concept, with only $5 \%$ of respondents stating that they never envisaged requiring the use of a peer 
mentor. However, students felt that the traditional face-to-face contact model was unnecessary, and $75 \%$ of respondents stated that virtual contact with a peer would be sufficient (Smailes et al. 2008). It was proposed that additional investigation to find a suitable virtual medium would be undertaken, and it is this scoping study that is the principal basis of the present paper.

\section{Peer mentoring and virtual formats}

In a report commissioned by the Joint Information Systems Committee (JISC 2008) the two most regular computer-based activities students undertake are use of university systems that support their learning (i.e. virtual learning environments [VLEs]) and accessing social networking sites. VLEs provide an integrated set of tools such as folders, email, quizzes and discussion boards to support learning (Svane and Smedley. 2004). Social networking sites provide space allowing individuals to create personal profiles and social commentary that can be publically shared (Boyd 2006).

Additionally, in an Eduserv report Kirriemuir (2008) examines the increasing number of UK universities that have a presence in virtual worlds. A prime example being Second Life, where users become residents known as avatars who interact either in fantasy or reality-based environments. Students make intensive use of online media including socialisation tools in their social lives (Cheng and Vassileva 2006) but the same technologies, with the exception of email, are less used for academic-related and support work.

There is little evidence of the existence of UK programmes of peer mentoring in virtual formats. The nearest cases being an Australian example (Dewart et al. 2003), in which email was used as the principal form of communication between mentor and mentees, and the work of Davis and Bullen (2004), a subject-specific example where a VLE was used to match Year four students as mentors to Year One students on a construction management project.

However, there is increasing interest in the potential of virtual support mechanisms. For example, Madge et al. (2009) explores social networking and observed how pre-registration engagement with the social networking site Facebook influences students' post-registration social networks. Students reported joining Facebook as a means of making new friends at university, as well as keeping in touch with friends and family at home. Once at university, Facebook formed part of the 'social glue' that helped students settle into university life but was just one aspect of students' more general social networking, both face to face and virtual. Students thought Facebook was used most importantly for social reasons, not for formal teaching purposes, although it was sometimes used informally for learning purposes.

Selwyn (2009) presents an in-depth qualitative analysis of the Facebook 'wall' activity of 909 undergraduate students in another UK university. Analysis of these data shows how much of students' education-related use of this social networking application was based around critiquing of/reflecting on learning experiences, exchange of factual information about teaching and assessment requirements and instances of requests for support (actual and moral) with regards to assessment or learning. Facebook was seen as place to discuss their personal identity as a student outside the confines of formal academic environments and therefore would appear relevant for undergraduates making the transition from school to higher education. 
Glasgow Caledonia University's initiative on Emergent Technologies for Learning is currently exploring how the Second Life virtual world can help students become more effective learners. In their i-CAMPUSS (Internet College Articulation and Mentoring Project for Prospective University Students), student mentors use Second Life to interact with first-year (and even prospective) students to explain things about schools and services that new students need to know. This service is specially aimed at international students (Glasgow Caledonia University 2009a).

In order to capitalise on the positive benefits of peer mentoring as a method of engaging students in communities of practice and to counteract the issues associated with mentee engagement in face-to-face programmes, this paper will examine three virtual formalised models of peer mentoring and scrutinise evidence both from the literature and using a case study from Northumbria University's student body to explore the arguments both for and against the connections between communities of practice and the three models proposed. Furthermore, as technology has the potential to begin the mentoring process before students arrive for the first-year induction period, capability of the technologies to do this will also inform the decision-making process.

In this instance, the three technologies under consideration are, respectively: Northumbria University's established learning and support tool, the VLE Blackboard; a social networking site (e.g. Facebook); and the virtual world Second Life. In the former case, selected due to its long-term (since the late 1990s) establishment at the university; the latter formats chosen on the emerging interest of their use as a support mechanism (Glasgow Caledonia University 2009b; Madge et al. 2009; Selwyn 2009).

\section{Methodology}

The first phase of the research methodology comprised a desk-based review of relevant literature that analysed and synthesised the outcomes of existing research and studies in the areas of interest (i.e. peer mentoring, communities of practice and new technologies). In doing this, a modified version of a systematic literature review was employed.

The researchers were engaged in searching, and together they built an EndNote library based on the retrievals, sharing selection and assessment criteria and key search terms (see Table 1). Online searches were used and these concentrated on a federated library search engine (especially databases in computing and business information systems, information and communication studies, and education). The researchers independently conducted searches around different areas of the project and then merged their resultant libraries, subsequently eliminating duplicates, whilst acknowledging that the existence of duplicates might add weighting to the value of the references since they had been retrieved via independent searches using different search strategies. The rationale for this approach was that it would ensure the selection of relevant, quality work from what was available using an efficient technique that minimised bias. Articles found were fully reference-checked by the researchers and briefly summarised. The contents of the EndNote library were analysed to develop an in-depth understanding of the current state of the topics under study and, based on the analysis, subject terms were derived and applied in order to be able to categorise the contents under subject headings. The final EndNote library contained more than 250 references. The ultimate selection of references to include 
Table 1. Search terms.

\begin{tabular}{|c|c|}
\hline $\begin{array}{l}\text { academic }+ \text { persistence } \\
\text { attendance } \\
\text { attrition } \\
\text { Blackboard } \\
\text { CAL or computer aided [or assisted] learning } \\
\text { collaborative + learning } \\
\text { collaborative + technologies } \\
\text { communication* } \\
\text { communities + learn* } \\
\text { communities + practice } \\
\text { course + completion } \\
\text { first + year + experience } \\
\text { emotional + competence } \\
\text { Enculturation } \\
\text { Facebook } \\
\text { high + risk + students } \\
\text { higher + education } \\
\text { integration } \\
\text { interaction } \\
\text { intercultural + skills } \\
\text { interventions } \\
\text { mentor } \\
\text { motivation } \\
\quad \text { networking }\end{array}$ & $\begin{array}{l}\text { new }+ \text { entrants } \\
\text { peer + assisted + learning } \\
\text { peer + educators } \\
\text { peer + learning, } \\
\text { peer + support } \\
\text { peer + teaching } \\
\text { peer + mentoring } \\
\text { retention } \\
\text { Second + Life } \\
\text { social + integration } \\
\text { social + media } \\
\text { social + networking } \\
\text { socialisation } \\
\text { students } \\
\text { student + attrition } \\
\text { student + experience } \\
\text { Supplement* + education or instruction } \\
\text { technolog* } \\
\text { undergraduate* } \\
\text { universit* } \\
\text { virtual + communit* } \\
\text { virtual + learn* + environment } \\
\text { virtual + worlds }\end{array}$ \\
\hline
\end{tabular}

Note: ${ }^{*}$ indicates truncation. +/or indicate use of Boolean operators. Terms were used in various permutations.

in the study was made on the basis of the appropriateness of the categorisations to the aims of the research. Final selections were evaluated by the researchers to improve the reliability of inclusion and, where differences arose, consensus was achieved by means of discussion.

The second phase of the research methodology involved a community consultation via a traditional survey approach in order to validate and extend the findings from the literature review. This was undertaken in order to establish current usage of social media within the context of one higher education institution, Northumbria University, and to explore the potential for developing a peer mentoring system via different social media. The survey method was chosen because it is fast and relatively inexpensive, whilst enabling the establishment of a baseline. For this exercise all of Northumbria University's on-campus students formed the population of interest and would be eligible to take part in the survey. After securing the appropriate ethical clearance, surveys were distributed both by hand (in social areas) and via the Internet (link provided in the Students' Union electronic newsletter) using SurveyMonkey.

Responses to the survey were received from 451 Northumbria University students. Around one-third of the respondents were male and two-thirds female; the majority of respondents (80\%) were in the 19-24 age group and responses were received from students in all of Northumbria University's nine academic schools and across all levels of study (i.e. foundation level to postgraduate). Over $20 \%$ of the respondents were non-UK students and $11 \%$ declared a disability - the majority of whom cited dyslexia. In terms of socio-economic status, over $50 \%$ of the cohort were first-generation students and around $40 \%$ of students noted they were the first 
of their sibling group to enter higher education. In all cases, the responses received were deemed to be representative of Northumbria University's student cohort.

\section{Results and discussion}

As a starting point, students were asked what most accurately reflected their access to the Internet. The vast majority of students $(82 \%)$ stated they had full private access to the Internet in their place of residence, with a further $12 \%$ saying they had frequent shared access. Furthermore, $79 \%$ of respondents indicated they have been Internet users for five years or more and $68 \%$ of respondents stating they had email accounts for five years or more, both observations being consistent across the different age groups surveyed. These figures indicate that students are both experienced users of email and the Internet, substantiating the viability of introducing virtual media in the peer mentoring process.

\section{Virtual learning environments}

VLEs typically provide an integrated set of tools for learning and teaching (Svane and Smedley 2004). There are numerous VLEs in operation but with over 5000 colleges and universities using WebCT or Blackboard these are viewed as the market leaders (MacLaren 2004). Northumbria University's VLE (Blackboard) has been in operation since the late 1990s. It is extremely well integrated into teaching and learning, with around two-thirds of survey respondents saying they access the VLE on a daily basis and a further 30\% stating they access the VLE on a weekly basis. This was the case across all demographic factors; that is, age, international students, disabled students, part-time students and first-generation students (students who are the first in their family to attend university). Burge (1994) comments that as a communication tool a VLE provides students opportunities to engage in social interactions with their peers alongside course-related conversations, with Sole and Lindquist (2001) amongst others (Gibbs 1999; Arbaugh 2000) noting the potential for VLEs to break down some social barriers found in the classroom, such as gender and nationality. There is some evidence that CoPs using discussion lists and VLEs have some benefit, particularly within professional practice (Ebenezer et al. 2003; Goos and Bennison 2008). In an extensive report reviewing Northumbria University students' use of the VLE conducted by Gannon-Leary and Turnock (2007), similar positive comment was received:

I agree that I could not successfully complete a module without the VLE site. I use VLE to allow me to interact with other students and lecturers via the discussion boards and it often helps when I am struggling with work, especially when I know others are also finding it difficult.

Ellaway, Dewhurst, and McLeod (2004) used Wenger's learning architecture framework to propose a method of evaluating a VLE as supporting an existing CoP, and found the value of the VLE is not in the software itself but dependent on its use and hence exists "in a 'blended' relationship with human activities" (Ellaway, Dewhurst, and McLeod 2004, 127). MacLaren (2004) comments that the commonest model in undergraduate teaching is that of a 'transmission' model, with Conole and De Laat (2006) observing that students were unenthusiastic about VLEs, citing 
them as an unimaginative repository for materials that was often poorly structured and used on an ad hoc basis. This was clearly illustrated through comments received in relation to the aforementioned Northumbria report by Gannon-Leary and Turnock (2007):

The VLE is certainly an effective addition to teaching in terms of the facility to post learning information and material. Sometimes it is an interesting addition to teaching. It depends on the lecturer and how they use it. It also depends on the student cohort. For example, one of my lecturers started a discussion board this semester which I thought was a really good idea and a good way to stimulate interest but no one bothered to post anything there!

I found that the VLE was not very exciting to the typical student that feels they have better things to do with their time. Unless the students are excited by the topic (which they should be) the VLE does not give off the impression of keeping people's attention for a long time.

Finally, students are not usually given access to the VLE until after enrolment, which means the virtual peer mentoring environment is unlikely to be available for use until after the induction period.

Therefore it is suggested that the very nature of institutional control of a VLE is likely to lead to difficulties in facilitating or engaging with social communities of informal and impromptu learning (O’Hear 2006).

\section{Social networking sites}

A social networking site is defined as one with profiles, and regular commentary on those profiles with a varying but publicly available social network (Boyd 2006). Liccardi et al. (2007) note how, owing to the perceived alignment with socialcultural theories of learning, social networking sites and their role within the students' learning experiences have an increasing and important role. Several researchers (Phipps 2007; Cain 2008; Ryberg and Christiansen 2008) have identified the potential for creating social learning environments that offer 'social communities of practice'.

Evidence suggests access to social networking sites is a day-to-day occurrence (Bausch and Han 2006). As noted by Tufekci (2008), multiple US studies have found that significant proportions of students $(>80 \%)$ have a social networking profile where it was found that around one-half considered themselves to be heavy users of such sites. When considering what drew students to such social networking one of Tufekci's $(2008,558)$, interviewees commented how they took "the work out of meeting people" as students were busy people and this cuts out one thing to do whilst "giving you the benefit you desire". Conversations surrounding social networking sites often make assumptions that in reality this is Facebook. However, as noted by Boyd and Ellison (2007), social networking engagement is culturally dependent - a particularly important consideration for the case study at Northumbria University, since $13.1 \%$ of students there are classed as international (the majority of whom originate from Asia). Therefore, it was felt that differences in usage by diverse students merited investigation. To investigate whether cultural differences exist, students at Northumbria University were asked about their use and knowledge of a number of social networking sites established as being used 
globally Although this list is not exhaustive, Table 2 clearly illustrates that Facebook is indeed the most widely used at Northumbria University with over threequarters of the respondents noting that they access it on a daily basis. This figure is $10 \%$ more than those accessing the VLE daily and over $70 \%$ more than the daily use of the second most popular social networking site - MySpace.

When examining the use of Facebook across the different diverse cohorts, international students were the group of particular interest and no significant differences were found in terms of Facebook use. Nevertheless, they were more likely to also use an additional social networking site on a regular basis - Orkut being popular with students from India. However, age was one factor where differences were observed, with students aged over 30 reporting that they were less likely to use any form of social networking. For all other demographic factors, social networking via Facebook was dominant.

However, Kolek and Saunders (2008) note how a number of US universities have increasing concerns in relation to social network sites. In their own study, which analysed student use of Facebook, it was revealed that only small proportions of students restrict access to their individual postings on the university network. Many students gave full disclosure of personal information, including photographs. It was observed that many of these individual postings could have "potential negative consequences for individual students", amplified by US media cases of sexual assault, stalking, and so forth, and a number of photographs displayed (e.g. alcohol fuelled) could cause "potential damage to an institution's image" (Kolek and Saunders 2008, 5).

In a separate study, Lipka (2007) comments on the complex difficulties that can arise through Facebook relationships; in particular, staff-student connections. Firstly, students in Lipka's study expressed the view that the site was their domain and as such needed free expression without worrying what professors might think. This is corroborated by Monteith and Smith (2001) and JISC (2008), the latter

Table 2. Social networking knowledge and use at Northumbria University 2008.

\begin{tabular}{lcccc}
\hline Social network & $\begin{array}{l}\text { Use daily } \\
(\%)\end{array}$ & $\begin{array}{l}\text { Use weekly } \\
(\%)\end{array}$ & $\begin{array}{l}\text { Occasionally or } \\
\text { rarely (\%) }\end{array}$ & $\begin{array}{c}\text { Don't use/not heard } \\
\text { of it (\%) }\end{array}$ \\
\hline Facebook & 76.2 & $13.1 \%$ & $4.2 \%$ & 6.5 \\
MySpace & 5.0 & 5.5 & 32.0 & 57.6 \\
Bebo & 3.8 & 3.1 & 17.1 & 76.1 \\
Orkut & 2.4 & 0.7 & 1.4 & 95.4 \\
Twitter & 1.4 & 1.4 & 4.6 & 92.5 \\
Friendster & 0.7 & 1.2 & 3.9 & 89.5 \\
Hi 5 & 0.7 & 1.2 & 8.6 & 97.1 \\
Xiaonel & 0.7 & 1.2 & 0.9 & 93.2 \\
Faceparty & 0.7 & 0.2 & 5.8 & 97.1 \\
Xanga & 0.5 & 0.2 & 2.2 & 98.0 \\
Tagged & 0.5 & 1.4 & 7.2 & 97.3 \\
Xing & 0.2 & 0.2 & 1.5 & 88.5 \\
Skyrock & 0.2 & 0.2 & 2.2 & 97.1 \\
Cyworld & 0.2 & 0.2 & 0.7 & \\
Friends Reunited & 0.2 & 0.7 & 10.6 & \\
Second Life & 0.0 & 0.2 & 2.6 & \\
\hline
\end{tabular}


reporting that although there is a "wide use of social networking students struggle how to see it can be used in learning" (JISC 2008, 10). Lipka (2007) additionally warns that students may also expect special privileges in the name of being a Facebook 'friend' citing requests such as asking to swap classes or assignment extensions as examples. Furthermore, Carnevale (2006) warns that one US college fell foul of Facebook's terms and conditions, which exclude an organisation setting up a user account for a group or entity; thus in creating a virtual mentor model, great care needs to be taken to ensure ownership lies with the mentors and not the institution per se.

In order to offset potential personal dangers and the reflection of some student entries on an institution, Kolek and Saunders $(2008,18)$ recommend that institutions at the very least "should develop clear policies and procedures for the use of Facebook and other social networking sites in (the name of) official institutional business" as well as use the induction process to warn students of the dangers of personal disclosure. If institutions begin to consider policies in relation to social network site use, students may begin to view the legitimate educational uses the university does support as imposed and hence suffer from the same negativity as the increasing current view of VLE use.

The group basis on which social networking sites like Facebook operate, as suggested Miller and Jensen (2007), focus on predefined activity as opposed to learning within a community. In traditional models of peer mentoring, the mentors have at least one full year of experience at university. However, if considering a basic dictionary definition of a mentor as a wise giver of advice, a student could pass on advice arising from their own personal discoveries at any time. Given that a number of Northumbria University students reported that their Facebook use began before entering higher education, where $73 \%$ had registered with pre-university email addresses, this process of passing on advice could also begin before the traditional induction periods.

\section{Virtual worlds}

Virtual worlds (e.g. Second Life), also referred to as three-dimensional multi-user virtual environments, have existed in some form since the early 1980s (Warburton 2009). Closely associated with computer gaming, virtual worlds have become of increasing interest to educators (Peachy 2007). One popular example is Second Life created by Linden Labs in 2003. Users who create avatar characters can purchase land and other items to create their own interactive graphic environments. Kirriemuir (2008) points out that Second Life creators claim that such spaces offer a community-based environment that mirrors reality - able to combine social CoPs with a personal learning environment, creating a 'learning network' that enables social and collaborative experiential learning.

Several UK universities have purchased land within the Second Life Grid to host their own support and learning environments (Shepard 2008), the basis of purchase being that the fantasy environment will allow real academic freedom for discussion. Salmon believes that with the use of Second Life avatar characters "there are not going to be the usual discrimination issues of the face-to-face environment ... the student and the teacher are on the same level" (Salmon quoted by Shepard 2008). However, Wetsch (2008) observes students' perception of a greater learning curve required to operate at a basic level within Second Life and Browne et al. (2008) 
note that staff skills were the greater challenge in incorporating virtual world technologies into learning. Salmon (2009) recognises that in Second Life strong scaffolding and support is likely to be required, but believes that if these barriers are overcome Second Life "is low cost and high value for learning" (Salmon 2009, $535)$.

Oliver and Carr (2009) applied Wenger's model of participation in CoP to couples that play World of Warcraft - a virtual world. They found analogies with distance learners, concluding that similar problems of retention faced by students studying at a distance (i.e. insufficient time to engage in activities and hence lack of socialisation) were as just as likely to occur when engaging in virtual world activity.

Warburton (2009) detects parallels within Second Life, the vast choice of communities deters casual use. Navigation, codes of etiquette, stigmatisation of a 'newbie' can lead to an isolating experience (Boostrom 2008). Cheal (2007, 204) has pronounced "that Second Life is not simply the latest online fad, but part of a continuum of instructional technology tools that corresponds to twentieth and twentyfirst century developments in educational theory", with Gartner Inc. (2007) predicting that $78 \%$ of Internet users will have a "second life" by 2011 .

The current picture at Northumbria University indicates knowledge and use of Second Life is much less than this. As illustrated in Table 2, only 12 of the 451 respondents indicated they used Second Life, most rarely, and all users were in the 19-24 age group. Notably, the only two regular users were international male students at Newcastle Business School from Hong Kong and China. Of the remaining 439 respondents, one-third have heard of Second Life but do not use it but, more surprisingly, two-thirds of the sample said they had no knowledge of the application.

Warburton (2009) also recognises that although the Second Life avatar characters do have real-life profiles they are limited and as such do not provide the level of social discovery that social networking sites like Facebook can provide. Finally, Edirisingha, Salmon, and Nie (2009) note that with any e-learning materials an academic as Second Life designer and moderator will be crucial in ensuring student engagement and success. Therefore, it may suffer from the same disadvantages as those currently experienced by the VLEs.

\section{Conclusions}

The traditional face-to-face peer mentoring model has had limited success at Northumbria University. Nonetheless, as this paper reports, previous research with students established that there was a demand for peer mentoring but that such demand was for 'needs-based' access to a mentor and that virtual contact with a mentor would be readily accepted.

Students were found to have frequent access to the Internet and hence would be able to access materials on any of the three virtual mentoring platforms under consideration. The VLE offers an established technological platform for mentoring since it is used regularly (in the majority of cases daily) by students. However, it lacks excitement, its use is directed by tutors post induction and it is mostly focussed on a repository role rather than that of a learning community. Therefore a VLE would be unlikely to engage students in peer mentoring activities. 
Social networking sites are heavily used by students and have popular appeal. There are a vast number of social networking sites available, the use of which can be culturally dependent. The primary research data (Table 2) established that Facebook was extensively and regularly used by all including international students - an initial concern. However, older students may be less likely to fall into the heavy user category. The potential for misuse and abuse indicates a potential necessity to introduce policies regarding Facebook usage, but this could have a negative impact on students who may resent the appropriation of one of their mechanisms for socialising by the institution.

Virtual worlds such as Second Life are increasingly being used by academic institutions. They offer a fantasy environment that has the potential to afford users academic freedom and break down barriers between academic staff and students, mentors and mentees. Currently Second Life is unfamiliar to most students and literature indicates that the skills associated with a virtual world environment have a greater learning curve on both the part of the designers and users. The basis under which Second Life operates is likely to require institutional purchase, and hence design of materials, like a VLE, is likely to come under institutional control.

The evidence presented here indicates that a model involving social networking sites has the greatest potential for supporting peer mentoring. This is due both to its immense popularity amongst the student body alongside the ability for mentoring to commence before formal student induction. It is proposed that, as mentors are students themselves, the site is unlikely to be negatively perceived as being under institutional ownership. However, in line with any mentoring programme, mentor training is essential and this instruction needs to include guidelines on insuring Facebook is used in a secure and professional manner.

Agreement has been established with one of Northumbria's academic schools to work with the authors to further explore a social networking-based model of peer mentoring. The pilot study involving students on marketing and business programmes will be analysed using participatory action research methods to ensure the mentoring process and materials provided warrant continued student engagement. It is expected that the outcomes from this pilot will inform a future paper establishing a new dimension in peer mentoring practice.

\section{References}

Arbaugh, J.B. 2000. Virtual classroom characteristics and student satisfaction with Internetbased MBA courses. Journal of Management Education 24, no. 1: 32-54.

Ashwin, P. 2002. Implementing peer learning across organisations: The development of a model. Mentoring and Tutoring 10, no. 3: 221-31.

Ashwin, P. 2003. Peer facilitation and how it contributes to the development of a more social view of learning. Research in Post-Compulsory Education 8, no. 1: 5-17.

Bausch, S., and L. Han. 2006. Social networking sites grow 47 percent, year over year, reaching 45 percent of web users. http://www.netratings.com/pr/pr_060511.pdf.

Best, G., D. Hajzler, and F. Henderson. 2007. Communicating with Chinese students offshore to improve their transition and adjustment to Australia - A pilot program. Journal of Academic Language and Learning 1, no. 1: A78-90.

Boostrom, R.E. 2008. The social construction of virtual reality and the stigmatized identity of the newbie. Journal of Virtual Worlds Research 1, no. 2: 1-19.

Boud, D., R. Cohen, and J. Sampson. 2003. Peer learning in higher education: Learning from and with each other. London: Kogan Page.

Boyd, D. 2006. Social network sites: My definition. http://zephoria.org/thoughts/archives/ 2006/11/10/social_network_1.html. 
Boyd, D.M., and N.B. Ellison. 2007. Social network sites: Definition, history, and scholarship. Journal of Computer-Mediated Communication 13, no. 1: 210-30.

Browne, T., R. Hewitt, M. Jenkins, and R. Walker. 2008. Survey of technology enhanced learning for higher education in the UK. Oxford: UCISA.

Burge, E.J. 1994. Learning in computer conferenced contexts: The learners' perspective. Journal of Distance Education 9, no. 1: 19-43.

Cain, J. 2008. Online social networking issues within academic and pharmacy education. American Journal of Pharmaceutical Education 72, no. 1: 10.

Carnevale, D. 2006. College tries to be cool but runs afoul of Facebook. Chronicle of Higher Education 153, no. 14: 39.

Cheal, C. 2007. Second Life: Hype or hyperlearning? On the Horizon 15, no. 4: 204-10.

Cheng, C., and J. Vassileva. 2006. Design and evaluation of an adaptative mechanism for sustained educational online communities. User Modeling and User-Adapted Interaction 16: $321-48$.

Clifton, R.A., R.P. Perry, C.A. Stubbs, and L.W. Roberts. 2004. Faculty environments, psychosocial dispositions and the academic achievement of college students. Research in Higher Education 45, no. 8: 801-28.

Congos, D., and B. Stout. 2003. Benefits of SI leadership after graduation. Research and Teaching in Developmental Education Fall: 1-9.

Congos, D., D. Langsham, and N. Schoeps. 1998. Inside supplemental instruction sessions: One model of what happens that improves grades and retention. Research and Teaching in Developmental Education 15, no. 1: 47-61.

Conole, G., and M. De Laat. 2006. Methodological issues with researching the student learning experiences. Presentation to the JISC Pedagogy Experts group meeting, February, in Birmingham, UK.

Crisp, G., and I. Cruz. 2009. Mentoring college students: A critical review of the literature between 1990 and 2007. Research in Higher Education 50, no. 6: 525-45.

Davis, P., and P. Bullen. 2004. Putting it together: Supportive strategies for learning and assessment using peer mentoring. Paper presented at the 3rd Asia-Pacific Conference Diversity and Equity in Continuing Education and Lifelong Learning, September 1, in Curtin University of Technology, Perth, Australia.

Devereux, L. 2004. When Harry met Sarita: Using a peer-mentoring program to develop intercultural wisdom in students. Paper presented at the Higher Education Research and Development Society of Australasia: Transforming knowledge into wisdom: Holistic approaches to teaching and learning, July 4-7, in Miri, Sarawak.

Dewart, H., D. Drees, P. Hixenbaugh, and D. Williams. 2003. Electronic peer mentoring: A scheme to enhance support and guidance and the student learning experience. Paper presented at Educause 2003, May 6-9, in Adelaide, Australia.

Ebenezer, J.V., F. Lugo, B. Beirnacka, and A. Puvirajah. 2003. Community building through electronic discussion boards: Pre-service teachers' reflective dialogues on science teaching. Journal of Science Education and Technology 12, no. 4: 397.

Edirisingha, P., G. Salmon, and M. Nie. 2009. 3-D multi-user virtual environments for socialisation in distance learning. Paper presented at the Association for Learning Technology Conference 2008, September 9-11, in University of Leeds, Leeds, UK.

Eggens, L., M.P.C. van der Werf, and R. Bosker. 2007. The influence of personal networks and social support on study attainment of students in university education. Higher Education 55, no. 5: 553-73.

Ehrich, L.C., B. Hansford, and L. Tennent. 2004. Formal mentoring programs in education and other professions: A review of the literature. Educational Administration Quarterly 40, no. 4: 518-40.

Ellaway, R., D. Dewhurst, and H. McLeod. 2004. Evaluating a virtual learning environment in the context of its community of practice. ALT-J, Research in Learning Technology 12, no. 2: $125-45$.

Farrell, H., C. Pastore, N. Handa, J. Dearlove, and E. Spalding. 2004. Initiating the battlers. Paper presented at ISANA Conference 2004, December, in Melbourne, Australia.

Gannon-Leary, P., and C. Turnock. 2007. Student use of the elearning portal. Internal report for elearning enhancement group, Northumbria University at Newcastle upon Tyne. 
Gartner Inc. 2007. Gartner says 80 percent of active internet users will have a 'Second Life' in the virtual world by the end of 2011. http://www.gartner.com/it/page.jsp?id=503861.

Gibbs, G.R. 1999. Learning how to learn using a virtual learning environment for philosophy. Journal of Computer Assisted Learning 15, no. 3: 221-31.

Glasgow Caledonia University. 2009a. i-CAMPPUS (internet College Articulation and Mentoring Project for Prospective University Students). http://caledonianblogs.net/sohsecondlife.

Glasgow Caledonia University. 2009b. Initiative on emergent technologies for learning. http://www.gcu.ac.uk/cuthere/projects.html.

Goos, M.E., and A. Bennison. 2008. Developing a communal identity as beginning teachers of mathematics: Emergence of an online community of practice. Journal of Mathematics Teacher Education 11, no. 1: 41-60.

Harvey, L., S. Drew, and M. Smith. 2006. The first-year experience. Briefing paper: Overview for higher education policy makers and practitioners. York, UK: Higher Education Academy.

Haythornthwaite, C. 2008. Learning relations and networks in web-based communities. International Journal of Web Based Communities 4, no. 2: 140-58.

Hensen, K.A. 2003. Impact of supplemental instruction: Results from a large, public, midwestern University. Journal of College Student Development 44, no. 2: 250-9.

Jacobi, M. 1991. Mentoring and undergraduate academic success: A literature review. Review of Educational Research 6, no. 4: 505-32.

Joint Information Systems Committee. 2008. Great expectations of ICT, how higher education institutions are measuring up. http://www.jisc.ac.uk/publications/publications/greatex pectations.aspx.

Kirriemuir, J.A. 2008. A Spring 2008 'snapshot' of UK higher and further education developments in Second Life. http://www.eduserv.org.uk/ /media/foundation/sl/uksnap shot052008/final\%20pdf.ashx.

Kolek, E.A., and D. Saunders. 2008. Online disclosure: An empirical examination of under graduate Facebook profiles. NASPA Journal 45, no. 1: 1-25.

Lave, J., and E. Wenger. 1998. Communities of practice: Learning, meaning, and identity. Cambridge: Cambridge University Press.

Liccardi, I., A. Ounnas, R. Pau, E. Massey, P. Kinnunen, S. Lewthwaite, M. Midy, and C. Sarkar. 2007. The role of social networks in students' learning experiences. $A C M$ SIGCSE Bulletin 39, no. 4: 224-37.

Lipka, S. 2007. For professors, 'friending' can be fraught. Chronicle of Higher Education 54, no. 15: 1 .

MacLaren, I. 2004. New trends in web-based learning: Objects, repositories and learner engagement. European Journal of Engineering Education 29, no. 1: 65-71.

Madge, C., J. Meek, J. Wellens, and T. Hooley. 2009. Facebook, social integration and informal learning at university: 'It is more for socialising and talking to friends about work than for actually doing work'. Learning, Media and Technology 34, no. 2: 141-55.

McLean, M. 2004. Does the curriculum matter in peer mentoring? From mentee to mentor in problem-based learning: A unique case study. Mentoring and Tutoring: Partnership in Learning 12, no. 2: 173-86.

Mee-Lee, L., and T. Bush. 2003. Student mentoring in higher education: Hong Kong Baptist University. Mentoring and Tutoring: Partnership in Learning 11, no. 3: 263-71.

Miller, S.E., and L.A. Jensen. 2007. Connecting and communicating with students on Facebook. Computers in Libraries 27, no. 8: 18-22.

Monteith, M., and J. Smith. 2001. Learning in a virtual campus: The pedagogical implications of students' experiences. Innovations in Education and Teaching International 38, no. 2: $119-32$.

Muldoon, R. 2008. Recognising and rewarding the contribution and personal development of peer supporters at university. Journal of Further and Higher Education 32, no. 3: 207-19.

O’Hear, S. 2006. e-learning 2.0 - how Web technologies are shaping education. http://www. readwriteweb.com/archives/e-learning_20.php. 
Oliver, M., and D. Carr. 2009. Learning in virtual worlds: Using communities of practice to explain how people learn from play. British Journal of Educational Technology 40, no. 3: 444-57.

Packham, G., and C. Miller. 2000. Peer assisted student support: A new approach to learning. Journal of Further and Higher Education 24, no. 1: 55-65.

Peachy, A. 2007. Education in Second Life. http://www.open.ac.uk/cetl-workspace/cetlcon tent/documents/48845a25f07ab.pdf.

Phipps, L. 2007. Web 2.0 and social software: An introduction. http://www.jisc.ac.uk/media/ documents/publications/web2socialsoftwarev1pdf.pdf.

Ryberg, T., and E. Christiansen. 2008. Community and social network sites as technology enhanced learning environments. Technology, Pedagogy and Education 17, no. 3: 207-19.

Salmon, G. 2009. The future for (second) life and learning. British Journal of Educational Technology 40, no. 3: 526-38.

Selwyn, N. 2009. Faceworking: Exploring students' education-related use of Facebook. Learning, Media and Technology 34, no. 2: 157-74.

Shepard, J. 2008. It's a world of possibilities, The Guardian, May 8. http://www.guardian. co.uk/education/2007/may/08/students.elearning.

Smailes, J., P. Gannon-Leary, C. Laing, and L. Conniss. 2008. Virtual mentor: An innovation in student support. Paper presented at Making Connections Conference, November 6, in London, UK.

Smith, C., and D. Bath. 2006. The role of the learning community in the development of discipline knowledge and generic graduate outcomes. Higher Education 51, no. 2: 259-86.

Sole, M., and L. Lindquist. 2001. Enhancing traditional, televised and videotaped courses with web-based technologies: A comparison of student satisfaction. Nursing Outlook 49, no. 3: 132-9.

Svane, T., and J. Smedley. 2004. Encouraging reflection using a bespoke virtual learning environment. Paper presented at Conference of the Australian Association for Research in Education, November 29-December 2, in Melbourne, Australia.

Tariq, V.N. 2005. Introduction and evaluation of peer-assisted learning in first-year undergraduate bioscience. Bioscience Education E-journal 6, no. 3: 1-19.

Terrion, J.L., and D. Leonard. 2007. A taxonomy of the characteristics of student peer mentors in higher education: Findings from a literature review. Mentoring and Tutoring: Partnership in Learning 15, no. 2: 149-64.

Tufekci, Z. 2008. Grooming, gossip, Facebook and MySpace. Information, Communication and Society 11, no. 4: 544-64.

Warburton, S. 2009. Second Life in higher education: Assessing the potential for and the barriers to deploying virtual worlds in learning and teaching. British Journal of Educational Technology 40, no. 3: 414-26.

Watson, J. 2000. Peer assistance support scheme (PASS) for first year core subjects. Paper presented at the Fourth Pacific Rim - First Year in Higher Education Conference: Creating Futures for the New Millennium, July 5-7, in Queensland University of Technology, Brisbane, Australia.

Wenger, E., R. McDermott, and W. Synder. 2002. Cultivating communities of practice: A guide to managing knowledge. Boston, MA: Harvard Business School Press.

Wetsch, L.R. 2008. The 'new' virtual consumer: Exploring the experiences of new users. Journal of Virtual Worlds Research 1, no. 2: 1-2.

Wubbels, T. 2007. Do we know a community of practice when we see one? Technology Pedagogy and Education 16, no. 2: 225-33. 